\title{
Effect of Temperature on Production Intracellular and Extracellular Invertase by Potential Indigenous Strain Kluyveromyces Marxianus Using Sugarcane Molasses
}

\author{
A.Q Laghari \\ Chemical Engineering Department, Mehran University of Engineering \\ \& Technology, Jamshoro, Pakistan \\ S.Aziz \\ Chemical Engineering Department, Mehran University of Engineering \\ \& Technology, Jamshoro, Pakistan \\ Arshad Iqbal \\ Chemical Engineering Department, Mehran University of Engineering \\ \& Technology, Jamshoro, Pakistan \\ A.Sami \\ Chemical Engineering Department, Quaid-e-Awam University of Engineering Science \\ \& Technology,Nawbshah, Pakistan \\ Farman Ali Shah \\ Mehran University of Engineering \& Technology, Jamshoro, Pakistan
}

\begin{abstract}
This study is focused on enzymolgy regarding enzyme purification technique and application of thermotolerant specie Kluyveromyces marxianus yeast in bio reactions for the research and optimization of fermentation temperature for intracellular and extracellular enzyme production. Fermentation studies were carried out in shake flask level to optimize intracellular and extracellular enzyme production by changing process conditions like temperature range from $\left(30\right.$ to $\left.55^{\circ} \mathrm{C}\right)$, the $\mathrm{pH}(5.5)$, speed $(350)$. The substrate type sugar cane molasses $15 \%$ added as a carbon and ammonium sulphate $(0.75 \%)$ as nitrogen source. The optimized fermentation temperature was found $45^{\circ} \mathrm{C}$, at $\mathrm{pH} \mathrm{5.5}$, and $\mathrm{rpm}$ was 350 . The production of intracellular invertase was $(890 \mu \mathrm{moles} / \mathrm{min} / \mathrm{g})$ while the extracellular $(120 \mu \mathrm{moles} / \mathrm{min} / \mathrm{g})$ Kluyveromyces marxianus was greater efficiency as compared to other specie because of its metabolic activity, which express more heat stability and Invertase activty upto $65^{\circ} \mathrm{C}$.
\end{abstract}

Keywords: Yeast, Fermentation, K.marxianus

DOI: $10.7176 / \mathrm{JNSR} / 9-9-02$

Publication date:May $31^{\text {st }} 2019$

\section{Introduction}

Nowadays, most of the people are suffer from daises due insufficient nutrient supply in the diets of human and feed of animals food[10]. Because of to this inconvenience, it is essential to propagate the manufacturing of protein with the help of all available technique. The situation of malnutrition in people living in developed and developing countries have become a growing concern as a result of deficiencies in food protein[11]. With the rapid growth of the world's population, high-pressure effects on the industry of food and the feed for producing sufficient human food and animal feed to meet demands of nutrition. The continual population resource of developing countries calls for increased and improved supply of human food and animal feed. The world's growing demand for protein rich foods has affected the formulation of alternative protein sources to be counterpart to conventional protein sources.

This growing world demand for food and feed proteins has led to the search for unconventional protein sources for supplementing conventional protein source. The companies dealing with animals feed are also facing under priced and over affected by conventional components, [1]

\section{MATERIALS AND METHODS}

\subsection{Purification of Strain}

Purification of current strain Kluyveromyces marxianus was done at biochemical engineering laboratory of Chemical engineering Department Mehran University of Engineering and Technology Jamshoro. [2] 


\subsection{Maintenance of Culture}

The practical work was carried out at biochemical laboratory of Department Chemical Engineering Mehran University of Engineering \& Technology Jamshoro. All analytical greade chemicals, glassware were purchased, oxide, and Dae-Jung companies from AL-Bourne and Shabbir Scientific Store Hyderabad. The black strip liquid (molasses) for fermentation was purchased from Khairpur and Rani pur District hairpur Mir's. Kluyveromyces marxianus culture was maintained as per methood [5,6] on Saboraud's Dextrose agar (SDA) slants and plates. Medium was prepared by the mixing of different analytical grade chemicals into distilled water one by one. The shaking volume was made up to $100 \mathrm{ml}$ in an Erlenmeyer flask of $250 \mathrm{ml}$ capacity. the $\mathrm{pH}$ of the medium was maintained up to 5.5 by using $\mathrm{HCl}$ and $\mathrm{NaOH}$

\subsection{Agar Plates preparation}

The following amounts of chemical composition were used for the preparation of agar plates as by. [2]

TABLE I. CHEMICALS OF NUTRIENT AGAR PLATE

\begin{tabular}{|c|c|}
\hline Chemicals & $\mathbf{\%}(\mathbf{w} / \mathbf{v})$ \\
\hline Agar & 3.0 \\
\hline Glucose & 2.0 \\
\hline Peptone & 0.5 \\
\hline Sodium chloride & 0.5 \\
\hline Yeast extract & 1.0 \\
\hline
\end{tabular}

Above chemical composition were used for the preparation of nutrient agar plates method mentioned by. [2,3]. These chemicals used as medium for the growth of microorganisms. about $50 \mathrm{ml}$ of distilled water was poured in $250 \mathrm{ml}$ Erlenmeyer flask followed their shaking. After that further water is added maintained up to 100 $\mathrm{ml}$ and $\mathrm{HCL}$ and Sodium $\mathrm{NaOH}$ used for proper maintenance of $\mathrm{pH}$ upto5.5.

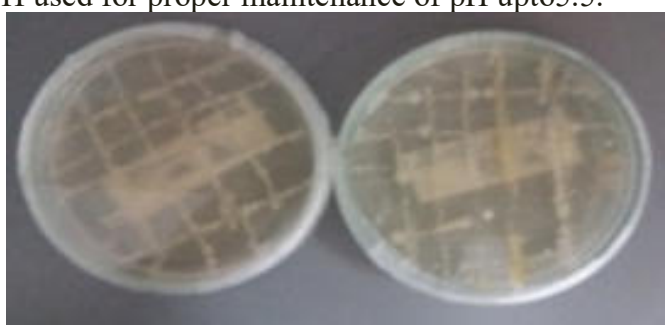

Fig. 1. Kluyveromyces marxians strain before purification

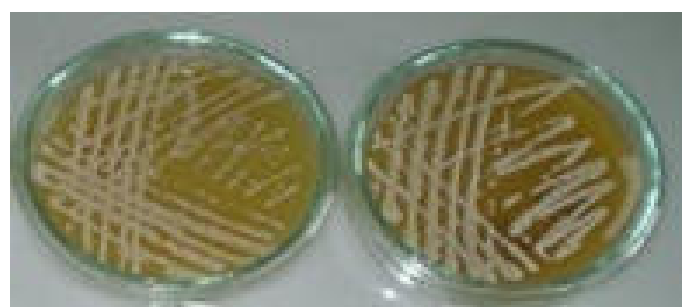

Fig. 2. Kluyveromyces marxians strain after purification

Purity of culture was checked in compound microscope before preparing inoculum the Fig. 1 shows the growth of Kluyveromyces marxians strain before purification when it was at raw state, after treatment the strain was purified shown in Fig. 2 for the proper application in the fermentation process for the production intracellular and extracellular enzyme production.[7,8,9]

\subsection{Sterilization}

The media was sterilized, at $121^{\circ} \mathrm{C}, 15 \mathrm{psi}$ pressure for $15 \mathrm{~min}$. then purity of medium was confirmed after different time interval ,24,48,72 hours. (Madihah et al., 2008; Madigan and Martinko, 2005).

\subsection{Preparation of Inoculum}

For yeast medium the inocula was prepared according to the following composition (w/v):[3] 
TABLE II. CHEMICAL COMPOSITION OF INOCULUM COMPOUND

\begin{tabular}{|l|l|}
\hline Chemical & $\mathbf{\%}(\boldsymbol{w} / \mathbf{v})$ \\
\hline Yeast Extract & 1.0 \\
\hline Sodium Chloride & 0.5 \\
\hline Glucose & 2.0 \\
\hline Peptone & 0.5 \\
\hline PH & 5.5 \\
\hline
\end{tabular}

\subsection{Preparation of Fermentation Medium}

Following composition of chemicals are use for the media preparation for fermentation.[2]

TABLE III: COMPOSITION OF CHEMICAL FOR FERMENTATION MEDIA

\begin{tabular}{|l|l|}
\hline Chemical & $(\mathbf{\%})$ age \\
\hline Carbon source (Sugar cane molasses) & 15 \\
\hline Nitrogen source (Di ammonium sulphate) & 0.75 \\
\hline PH & 5.5 \\
\hline Inoculums & 0.5 \\
\hline
\end{tabular}

\section{RESULT AND DISCUSSION}

Fermantation studies were undertaken to optimize the temperature by changing process temperature. fermentation for growth of $K$. marxianus, in the presence of various temperatures, $\left(30^{\circ} \mathrm{C}\right.$ to $\left.65^{\circ} \mathrm{t} \mathrm{C}\right)$ speed $(350$ $\mathrm{rpm}) \mathrm{pH}$ (5.5) for the substrate consumption and invertase production. Molasses were employed to study their effect on growth and production. The intracellular and the extracellular enzyme production at $45^{\circ} \mathrm{C}$ by indigenous strain K. marxianus with $15 \%$ sugar concentration of substrate gave the maximum amount of intracellular $(890 \mu \mathrm{moles} / \mathrm{min} / \mathrm{g})$ and the extracellular $(150 \mu \mathrm{moles} / \mathrm{min} / \mathrm{g})$ enzyme. The optimum intracellular and the extracellular enzyme was observed after $48 \mathrm{~h}$ of fermentation with media containing blackstrap molasses ( $15 \%$ total reducing sugars), the optimized temperature was $45^{\circ} \mathrm{C}, \mathrm{pH} 5.5$ and speed $300 \mathrm{rpm}$.

Table IV: Effect of temperature on the extracellular enzyme production at $\mathrm{pH} 5.5,350 \mathrm{rpm}$ and 48 hours.

\begin{tabular}{|l|l|l|}
\hline & & \\
Temp $={ }^{\mathbf{}} \mathbf{C}$ & Sugar/Molasses $\mathbf{g} / \mathbf{l}$ & Extracellular Activity $(\boldsymbol{\mu m o l e s} / \mathbf{m i n} / \mathbf{g})$ \\
\hline 30 & 150 & 0 \\
\hline 35 & 120 & 450 \\
\hline 40 & 90 & 700 \\
\hline 45 & 60 & 890 \\
\hline 50 & 25 & 850 \\
\hline 55 & 5 & 800 \\
\hline
\end{tabular}

The above mentioned table IV, the various temperatures was applied from $\left(30^{\circ} \mathrm{C}\right.$ to $\left.55^{\circ} \mathrm{C}\right)$ in fermentation process in order to investigate the optimized temperature for enzyme production. At $45^{\circ} \mathrm{C}$ temperature the maximum production of extracellular enzyme was obtained. The extracellular enzyme production was (890 $\mu \mathrm{moles} / \mathrm{min} / \mathrm{g}$ ).

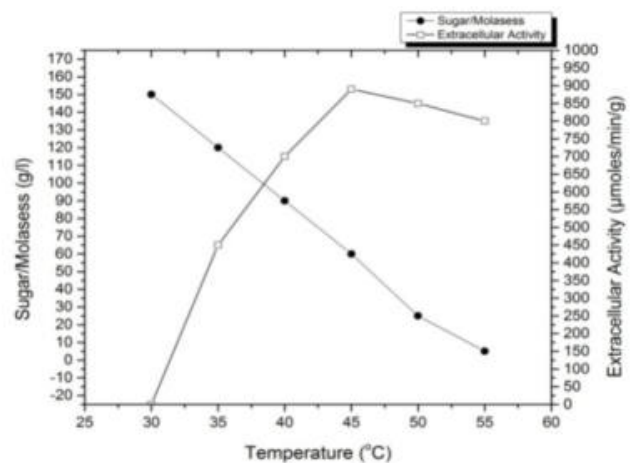

Fig. 3. Temperature Effect On The Production Of Intracellular Activity at various temperatures. 
Table V. Effect of temperature on the extracellular enzyme production at pH 5.5, 350rpm and 48 hours.

\begin{tabular}{|l|l|l|}
\hline $\begin{array}{l}\text { Temp }= \\
{ }^{\circ} \mathbf{C}\end{array}$ & $\begin{array}{l}\text { Sugar/Molasses } \\
\text { g/l }\end{array}$ & $\begin{array}{l}\text { Intracellular } \\
(\boldsymbol{\mu m o l e s} / \mathbf{m i n} / \mathbf{g})\end{array}$ \\
\hline 30 & 150 & 0 \\
\hline 35 & 120 & 60 \\
\hline 40 & 90 & 140 \\
\hline 45 & 60 & 150 \\
\hline 50 & 25 & 140 \\
\hline 55 & 5 & 130 \\
\hline
\end{tabular}

In table 5 , the various temperatures $\left(30^{\circ} \mathrm{C}\right.$ to $\left.55^{\circ} \mathrm{C}\right)$ was applied from $\left(30^{\circ} \mathrm{C}\right.$ to $\left.55^{\circ} \mathrm{C}\right)$ in fermentation process in order to determine optimized temperature for production of enzyme. The best temperature was $45^{\circ} \mathrm{C}$ for production of intercellular enzyme. The intercellular enzyme production was $(150 \mu \mathrm{moles} / \mathrm{min} / \mathrm{g})$.

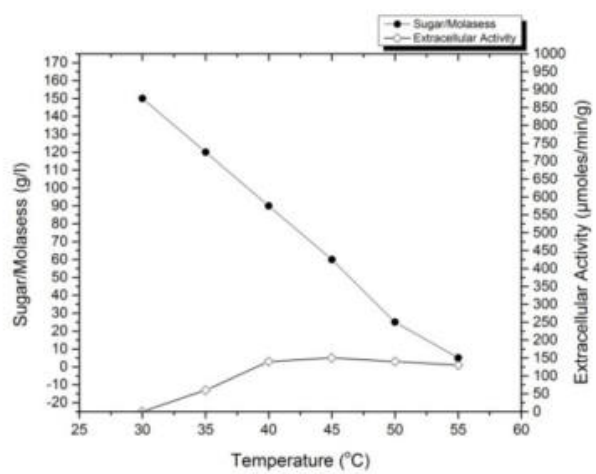

Fig. 4. Temperature Effect On The Production Of Intracellular Activity at various temperatures.

\section{CONCLUSION}

It is concluded that the indigenous strain Kluyveromyces marxianus can work at high temperature up to $65^{\circ} \mathrm{C}$ and at optimum temperature $40^{\circ} \mathrm{C}, \mathrm{pH} 5.5$, and speed $300 \mathrm{rpm}$ it gives maximum intracellular and the extracellular enzyme production. It is economically feasible for large scale production because it reduces the cooling cost. In Pakistan it can be use to produce the enzyme which can be utilize as food supplement to overcome on the malnutrition problem.

\section{ACKNOWLEDGEMENT}

My deepest feeling of thanks and appreciations are to my Department of Chemical Engineering, Mehran University of Engineering and Technology Jamshoro, Pakistan for providing me best research facilities and a great deal of knowledge that helped me to achieve my goals and Objective of my research.

I feel a great pleasure and honor to express my heart full gratitude to my supervisor Prof. Dr. Shaheen Aziz, and Co-supervisor, Prof. Dr. Syed Farman Ali Shah, for their proper guide line, technical support and sympathetic attitude throughout my experimental work at MUET.

\section{References}

[1] G. Suman, M. Nupur, S. Anuradha, B. Pradeep"International Journal of current micro biology and applied science" Single Cell Protein Production, Vol. 4, No. 9, pp. 251-262, 2015

[2] S. Aziz, H. Rehman Memon, F. Ali Shah,M.Ibrahim Rajoka, S. Ahmed Soomro" Production of Ethanol by Indigenous Wild and Mutant Strain of Thermotolerant Kluyveromyces Marxianus Under Optimized Fermentation Conditions" Pak. J. Anal. Environ. Chem. Vol. 10, No. 1 \& 2 2533, 2009

[3] F. Ali Shah S. Aziz, H. Rahman Memon, Z. M Ali, M.Ibrahim Rajoka "Enhanced Production of Invertase from Thermoltolerant Yeast Through Black Strap Molasses a Waste Prodcut of Sugar Industry" Australian Journal of Basic and Applied Sciences, Vol.5 No.1, 48-54, 2011

[4] M. Shuler "Investigation of the Performance and Kinetics of Anaerobic Digestion at $45^{\circ} \mathrm{C}$ "Journal of Water Resource and Protection. Vol.7 No.14, 2015

[5] M. Ibrahim Rajoka, F. Latif, S. Khan and R. Shahid, "Kinetics of improved productivity of $\beta$ galactosidase by a cycloheximide resistant mutant of Kluyveromyces marxianus. Biotechnol" Lett. 26 (2004) 714.

[6] M. Ibrahim Rajoka, S. Khan, R. Shahid" Regulation of Galactosidase Production from K. marxianus" Food Technol. Biotechnol. Vol.41, No.4, pp.315-320 2003

[7] I. Banat, R.Merchant, "Isolation of thermotolerant, fermentative yeasts growing at $52{ }^{\circ} \mathrm{C}$ and producing ethanol 
at $45^{\circ} \mathrm{C}$ and $50^{\circ} \mathrm{C}$ ". World J. Microbial Biotech.V.8, pp. 259-263, 1992.

[8] S. Limtong, W.Yongmanitchai, "Production of fuel ethanol at high temperature from sugar cane juice by a newly isolated Kluyveromyces marxianus," Letters in App: Microbial. V. 98, pp.3367-3374. 2007

[9] Brady, D. Logan, S.R, McHale, "The effect of soluble alginate and calcium on b-galactosidase activity produced by the thermotolerant, ethanol-producing yeast strain Kluyveromyces marxianus” Bioproc Eng, V.18, pp. 101-104, 2007

[10] U. Bacha, M. Nasir, A. Khalique, A. A. Anjum, and M. A. Jabbar" comparative assessment of various agroindustrial wastes for saccharomyces cerevisiae biomass and its quality evaluation as single cell protein" The Journal of Animal \& Plant Sciences, Vol. 21, No.4, pp. 844-849, 2011, Page:

[11] K. Hanim, A.Rahman, S. J Hanim, M. Yusof Z. Zakaria"Bioproteins Production from Palm Oil AgroIndustrial Waste"Pertanika J. Trop. Agric. Sci. Vol.39, No. 1, pp. 29 - 39, 2016 